\title{
Efficacy of Locust Beans Husk Char in Heavy Metal Sequestration
}

\author{
Ademola A. Ajayi-Banji ${ }^{1}$, Temitayo A. Ewemoje ${ }^{2}$, and Adeniyi A. Ajimo ${ }^{3}$ \\ ${ }^{1}$ Agricultural and Biosystems Engineering Department, Faculty of Engineering and Technology, University of \\ Ilorin, Ilorin, Kwara State, Nigeria \\ ${ }^{2}$ Agricultural and Environmental Engineering Department, Faculty of Technology, University of Ibadan, Ibadan, \\ Oyo State, Nigeria \\ ${ }^{3}$ Civil Engineering Department, School of Engineering, Yaba College of Technology, Jibowu, Lagos State, \\ Nigeria
}

Correspondence author:

A. A. Ajayi-Banji, Agricultural and Biosystems Engineering Department, Faculty of Engineering and

Technology, University of Ilorin, Ilorin, Kwara State, Nigeria

E-mail: ajayibanjiademola@gmail.com

(received in September 2015; accepted in December 2015)

\begin{abstract}
Most solid waste management schemes minimally consider low concentration biodegradable agricultural waste management, though the environmental impact of this waste category is significant over a time frame. The column-mode study seeks to address the issue by suggesting potential utilisation of post-harvest waste for heavy metal sequestering. Locust beans husk char of 100 and $200 \mathrm{~g}$ was employed to inspect removal efficiency, isotherm and kinetic models of some heavy metals at 30, 60, 90, 120 and 150 min contact time. Elemental composition of the biosorbent was investigated using the SEM-EDX machine. The results obtained depict that over $85 \%$ aluminium and nickel removal was achieved at $150 \mathrm{~min}$ detention time. The Freundlich isotherm well described most of the sorbates sorption $\left(\mathrm{R}^{2} \geq 0.91\right)$. The sorption rate equally fitted into the second-order pseudo kinetic model $\left(\mathrm{R}^{2} \geq 0.88\right)$. Ion exchange took place during the sorption. Locust beans husk has promising adsorption potential in heavy metal ions removal from fouled surface water.
\end{abstract}

Keywords: post-harvest waste, removal efficiency, isotherm, kinetic sorption, locust beans husk char (LHC).

\section{Introduction}

Solid waste management is a topical issue due to rate and volume of daily solid waste generation and subsequent effects on the ecosystem. The estimated global municipal solid waste generation per capita per year is 0.1 to $0.8 \mathrm{t}$ (Bogner et al., 2007). The principal reaction to the growing and poorly managed subject particularly in the developing and underdeveloped world is attributed to environmental concern in all its extant forms. The forms are inert, toxic, biodegradable or nonbiodegradable. The compositions are metal, food, wood, plastic, glass and paper. Most of the aforementioned constituents are harnessed with modern technologies through recycling, energy recovery and reuse. However, some post-harvest wastes have not gained such interest. Post-harvest wastes are unwanted materials that enclose or are part of the useful crop materials often transported to the processing unit after harvest. The wastes are left bare with little or no good management practice administered mainly because of low concentration in terms of odour and subsequent natural biodegradation, yet the wastes are valuable if correctly utilised. Areas of interest in the application of post-harvest wastes are woodchip in composting (Hanc et al., 2012), pozzolanic material in concrete production (Ndububa \& Uloko, 2015) and contaminants removal (Sivakumar \& Palanisamy, 2009; Omotosho \& Sangodoyin, 2013). The latter application could be streamlined to undesirable 
substances removal from air and water by the adhesion on the adsorbent produced from postharvest waste. This treatment method is called adsorption. Contaminants are attached to the adsorbent so that it becomes component of the molecular structure. A number of biomass materials and agricultural wastes have been investigated through this eco-friendly treatment method with remarkable percent removal obtained. Maize tassel (Sekhula et al., 2012), lignin (Bailey et al., 1999) and wood ash (Chojnacka \& Michalak, 2009) are examples of such materials. Other adsorption assessment tools are isotherm and adsorption kinetic. These evaluation tools examine adsorbent effectiveness in relation to the selected sorbate. Hence, the study investigates carbonised post-harvest waste (locust beans husk char) usability as biosorbent in some heavy metal removal from mildly polluted surface water.
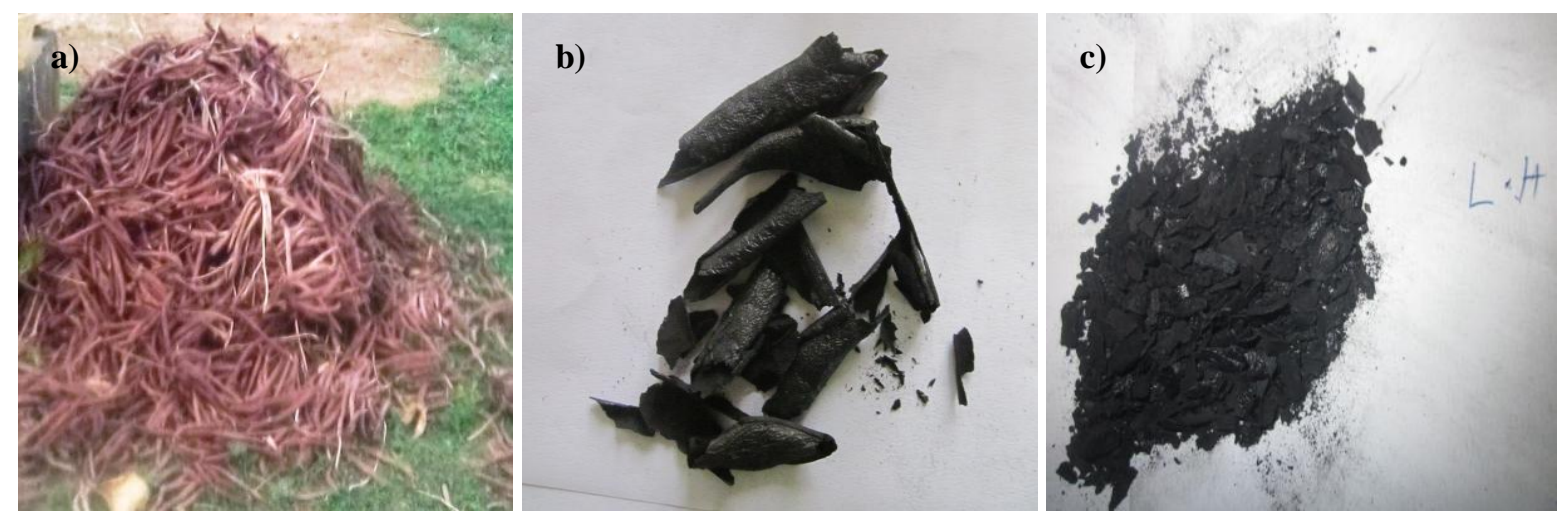

Figure 1. Different structures of locust beans husk: a) pile of locust beans husk; b) carbonised locust beans husk; c) granulated locust beans husk char.

\section{$2 \quad$ Materials and methods}

Locust beans husks obtained from a local farmer (Figure 1a) were cleaned and wrapped with doubled-layer aluminium foil to ensure carbonisation under hermetic conditions. The biomass was pyrolysed at $350{ }^{\circ} \mathrm{C}$ for a period of $60 \mathrm{~min}$. Char produced was reduced in size for adsorption rate enhancement and sorted with 1,400 microns sieve before storage (Figure 1b, 1c). The sorbent was examined with the EDX machine for variation in chemical composition before and after carbonisation. Two plastic cylindrical reactors of $41 \mathrm{~cm}$ in height and $11 \mathrm{~cm}$ in diameter were underlaid with $50 \mathrm{~g}$ of an absorbent (cotton wool) before the introduction of a biosorbent and then overlaid with another $50 \mathrm{~g}$ of an absorbent. The choice of a cylindrical reactor was to prevent pocket formation at the angles of the system wall (Ajayi-Banji, 2012). Granulated locust beans husk char (LHC) of 100 and $200 \mathrm{~g}$ was placed in the $1,300 \mathrm{~cm}^{3}$ mean volumetric capacity reactors. The water sample was collected under stringent conditions along Pipeline Road in Ilorin, Kwara State, Nigeria. The choice of the source was due to its location, which made it a discharge point for surrounding industrial and residential buildings. The water source equally serves irrigation purposes. The collected surface water (18 L) was gradually injected into the reactor at a suitable flow rate $(14 \mathrm{~mL} / \mathrm{min})$ to ensure the efficient biosorption process. Kumar et al. (2007) recommended a flow rate within this limit for good adsorbability. The treated influent was discharged into receiving containers after detention times of 30, 60, 90, 120 and 150 min for heavy metal inspection. Contaminant analysis in the treated and untreated water samples was carried out in replicates twice to cater for possible variations.

\subsection{Experimental calculation}

Removal efficiency, Freundlich and Langmuir models in linear representation and pseudo firstand second-order kinetic models after integration with boundary conditions are expressed by equations 1-6.

$$
\begin{gathered}
\text { Removal efficiecy }=\left(C_{o}-C_{t}\right) C_{o} \times 100 \\
Q_{t}=\frac{\left(C_{o}-C_{t}\right) V_{t}}{W_{b}} \\
\log Q_{t}=\log K+\left(\frac{1}{n}\right) \log C_{t} \\
\frac{C_{t}}{Q_{t}}=-\frac{1}{Q_{m} \cdot K_{L}}+\frac{C_{t}}{Q_{m}} \\
\log \left(Q_{e}-\frac{Q_{t}}{}\right)=\log _{e}-\left(\frac{K_{Q}}{2.3038}\right) t \\
\frac{t}{Q_{t}}=\frac{1}{K_{p} Q_{e}{ }^{2}}+\frac{t}{Q_{e}}
\end{gathered}
$$


where $C_{0}$ indicates the initial concentration of a heavy metal in a water sample before treatment with LHC $(\mathrm{mg} / \mathrm{L}) ; C_{t}$ indicates the concentration of a heavy metal in effluent after treatment for a particular contact time $(\mathrm{mg} / \mathrm{L}) ; Q_{t}$ indicates the quantity of a heavy metal adsorbed per LHC unit weight at a given detention time $(\mathrm{mg} / \mathrm{g}) ; Q_{e}$ indicates the quantity of a heavy metal adsorbed per adsorbent unit weight equilibrium $(\mathrm{mg} / \mathrm{g}) ; V_{t}$ indicates the volume of water in the adsorption column at a definite contact time $(\mathrm{L}) ; W_{b}$ is the mass of LHC $(\mathrm{g})$; $t$ indicates retention time in hrs; $Q_{m}$ signifies the maximum adsorptive capacity of a heavy metal $(\mathrm{mg} / \mathrm{g})$ and $K$ is the Freundlich constant related to the extent of adsorption (mg/g); $n$ is related to the adsorption intensity. Values of $\mathrm{K}$ and $\mathrm{n}$ are constants deduced from the intercept and slope of plot of $\log Q_{t}$ against $\log C_{t} . K_{L}$ and $Q_{m}$ are obtained from the intercept and slope of plot of $C_{t} / Q_{t}$ against $C_{t}$. Constants $K_{Q}(\mathrm{~L} / \mathrm{min})$ and $K_{p}(\mathrm{~g} / \mathrm{mg} / \mathrm{min})$ are firstand second-order pseudo kinetic rates calculated

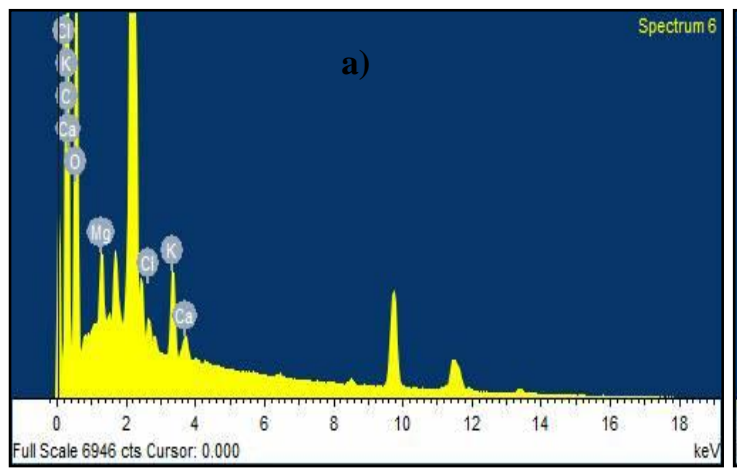

Figure 2. EDX for locust beans: a) husk; b) char.

\subsection{Removal efficiency}

Removal percentage was high at the first $30 \mathrm{~min}$ of the sorption process for iron, copper, nickel and manganese at $100 \mathrm{~g} \mathrm{LHC}$. The similar result was obtained for aluminium, manganese and nickel at $200 \mathrm{~g}$ LHC. This might be attributed to more active sites within the biosorbent at the initial stage and strong interaction between the adsorbent and sorbates. Low sorbate sorption observed for some metals despite active biosorbent sites infers that other factors influence heavy metal removal (Tables 1 \& 2). Factors documented in literature include sorbate type, detention time, activation, biosorbent dose and adsorbent type (Emmanuel \& Veerabhadra Rao, 2009; Ijaola et al., 2013). Removal efficiency was high in aluminium and nickel between $85-89 \%$ at 150 min retention time. This is an indication that from the slope of plot $\log \left(Q_{e}-Q_{t}\right)$ versus $t$ and slope and intercept of $t / Q_{t}$ versus $t$, correspondingly.

\section{Results and discussion \\ 3.1 Biosorbent composition}

Carbon, chlorine, potassium, calcium and oxygen are elements noteworthy in the precursor and biosorbent (Figure 2a, 2b). Carbonisation influenced the chemical properties of the adsorbent. Calcium and potassium quantity per mass of elemental constituents increased by $57 \%$ and $30 \%$, respectively, while carbon decreased by $5.4 \%$ after carbonisation. Calcium ion in biosorbents plays an important role during adsorption. According to Wilson et al. (2003), ions trade-in occurs with the biosorbent that contains some level of calcium. Hence, the high locust beans husk char calcium content will possibly boost heavy metal removal.

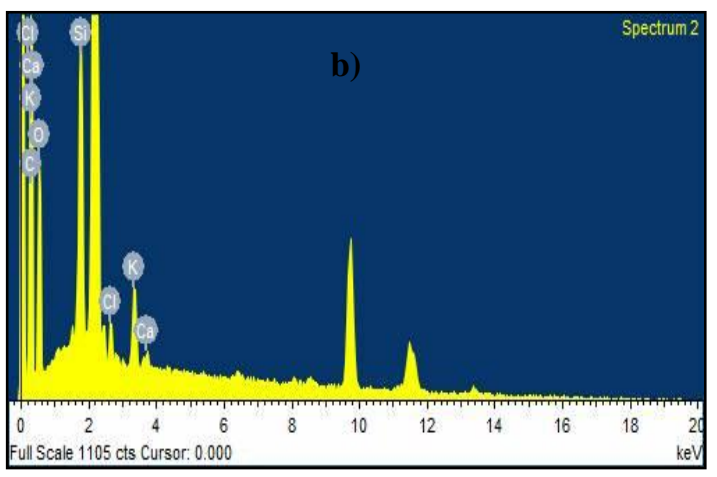

LHC has high affinity for aluminium and nickel sequestration in polluted surface water. Optimal removal efficiency was not achieved for the sorbates within this contact period for this study. Sangodoyin and Ajayi-Banji (2013) recommended higher contact time for metal removal by biosorbents. Lurtwitayapont and Srisatit (2010) also led credence to this finding in a study of lead removal on bone char. Adsorbent dosage has a declining effect on percent removal for most heavy metals after $30 \mathrm{~min}$ retention time except nickel. An increase in LHC dosage from 100 to $200 \mathrm{~g}$ does not result in a proportionate increase in removal efficiency. This is an indication of weak interaction between increased mass of LHC (200 g) and adsorbate (Tables 1 \& 2). This confirms that retention time does not have autonomous influence on the contaminant sorption rate.

Table 1. Removal efficiency for $100 \mathrm{~g}$ LHC.

\begin{tabular}{||c|c|c|c|c|c||}
\hline \multirow{2}{*}{ Heavy metal } & \multicolumn{5}{|c||}{ Removal efficiency (\%) } \\
\cline { 2 - 6 } & $\mathbf{3 0}$ min & 60 min & 90 min & 120 min & 150 min \\
\hline Iron & 31.43 & 36.67 & 38.57 & 48.57 & 53.33 \\
\hline Zinc & 5.833 & 38.33 & 38.33 & 42.50 & 45.83 \\
\hline Copper & 26.67 & 36.67 & 43.33 & 50.00 & 56.67 \\
\hline Aluminium & 3.700 & 67.41 & 74.82 & 76.30 & 86.67 \\
\hline Manganese & 25.00 & 50.00 & 66.66 & 79.17 & 82.00 \\
\hline Nickel & 42.86 & 66.67 & 71.43 & 76.19 & 85.71 \\
\hline
\end{tabular}


Table 2. Removal efficiency for $200 \mathrm{~g}$ LHC.

\begin{tabular}{|c|c|c|c|c|c||}
\hline \multirow{2}{*}{ Heavy metal } & \multicolumn{5}{|c|}{ Removal efficiency (\%) } \\
\cline { 2 - 6 } & $\mathbf{3 0}$ min & $\mathbf{6 0}$ min & $\mathbf{9 0}$ min & $\mathbf{1 2 0}$ min & 150 min \\
\hline Iron & 10.95 & 24.76 & 26.19 & 39.52 & 39.52 \\
\hline Zinc & 11.67 & 20.83 & 35.83 & 40.83 & 60.83 \\
\hline Copper & 6.670 & 13.33 & 20.00 & 30.00 & 33.33 \\
\hline Aluminium & 44.44 & 67.41 & 68.15 & 72.59 & 88.89 \\
\hline Manganese & 33.33 & 37.50 & 41.67 & 54.17 & 54.17 \\
\hline Nickel & 66.67 & 76.19 & 80.95 & 85.71 & 85.71 \\
\hline
\end{tabular}

\subsection{Freundlich and Langmuir isotherm models}

Isotherm suitability investigated shows that Freundlich well described heavy metal sorption on LHC surface with correlation coefficient values greater than 0.91 in all cases. This trend differs for Langmuir, where the correlation coefficient values were less than 0.81 except for iron and manganese at 100 and $200 \mathrm{~g}$ LHC dosage, respectively (Tables $3 \&$ 4). This infers that the sorption process was principally multilayer and applies to heterogeneous surface (Lurtwitayapont and Srisatit, 2010). According to Moreno et al. (2010), n value less than unity under a multilayer condition is an indication of considerable adsorption of heavy metals at higher sorbate concentration. Table 3 follows this pattern (n $<1$ ); hence, LHC at 100 and $200 \mathrm{~g}$ has the tendency to adsorb more heavy metals at higher sorbate concentration. Adsorption intensity is denoted by $\mathrm{k}$ value, and high $\mathrm{k}$ value depicts high adsorption intensity. The high $\mathrm{k}$ values for aluminium, nickel and manganese compared with other metals (Table 3) substantiate the obtained removal efficiency result. Biosorbent dosage has no significant influence on adsorption intensity. It can be deduced that the inspected metal ions have higher $\mathrm{k}$ value at $100 \mathrm{~g}$ compared with a $200 \mathrm{~g}$ sorbent dose (Table 3).

Table 3. Freundlich isotherm parameters for LHC.

\begin{tabular}{||c|c|c|c|c|c|c||}
\hline \multirow{2}{*}{ Heavy Metal } & \multicolumn{3}{|c|}{$\mathbf{1 0 0} \mathbf{g}$} & \multicolumn{3}{c|}{$\mathbf{2 0 0} \mathbf{g}$} \\
\cline { 2 - 7 } & $\boldsymbol{R}^{\mathbf{2}}$ & $\boldsymbol{k ( \times \mathbf { 1 0 } ^ { - 3 } )}$ & $\boldsymbol{n}$ & $\boldsymbol{R}^{2}$ & $\boldsymbol{k}\left(\times \mathbf{1 0}^{-3}\right)$ & $\boldsymbol{n}$ \\
\hline Iron & 0.9989 & 21.980 & 0.9103 & 0.9965 & 7.6000 & 0.6282 \\
\hline Zinc & 0.9407 & 14.700 & 0.4174 & 0.9933 & 12.100 & 0.5738 \\
\hline Copper & 0.9999 & 22.000 & 0.7682 & 0.9986 & 5.1600 & 0.6036 \\
\hline Aluminium & 0.9153 & 151.00 & 0.1730 & 0.9932 & 85.900 & 0.6248 \\
\hline Manganese & 0.9914 & 525.20 & 0.4379 & 0.9975 & 31.100 & 0.8950 \\
\hline Nickel & 0.9981 & 371.30 & 0.5755 & 0.9996 & 308.00 & 0.5260 \\
\hline
\end{tabular}

Table 4. Langmuir isotherm correlation coefficient for LHC.

\begin{tabular}{||c|c|c||}
\hline Heavy Metal & $\mathbf{1 0 0} \mathbf{g} \boldsymbol{R}^{2}$ & $\mathbf{2 0 0} \mathbf{g} \boldsymbol{R}^{\mathbf{2}}$ \\
\hline Iron & 0.9051 & 0.4338 \\
\hline Zinc & 0.1331 & 0.3652 \\
\hline Copper & 0.8030 & 0.4330 \\
\hline Aluminium & 0.5726 & 0.4788 \\
\hline Manganese & 0.0546 & 0.9058 \\
\hline Nickel & 0.3260 & 0.7556 \\
\hline
\end{tabular}

\section{$3.4 \quad$ Pseudo kinetic sorption}

Metals kinetic sorption did not follow firstorder kinetics $\left(\mathrm{R}^{2}<0.35\right)$. On the contrary, the second-order pseudo kinetic model gave better representation for most metals except zinc and aluminium at a $100 \mathrm{~g}$ LHC dose. The correlation coefficient values were greater than 0.88 (Tables $5 \&$ $6)$. LHC sorbate sorption described by pseudo- second-order rate equation shows close values of calculated $Q_{t}$ and experimental $Q_{e}$ values computed from the plot of $t / Q_{t}$ against $t$ (Table 6). Minimal disparity between calculated and experimental values of adsorption kinetics validates the applicability of pseudo second order. The consistency is an indication of the chemisorption process (Dizadji et. al., 2011).

Table 5. First-order pseudo kinetics parameters for LHC.

\begin{tabular}{||c|c|c|c|c||}
\hline \multirow{2}{*}{ Heavy metal } & \multicolumn{2}{|c|}{$100 \mathbf{g}$} & \multicolumn{2}{c|}{$\mathbf{2 0 0} \mathbf{g}$} \\
\cline { 2 - 5 } & $\boldsymbol{R}^{2}$ & $\boldsymbol{K}_{q}$ & $\boldsymbol{R}^{2}$ & $\boldsymbol{K}_{\boldsymbol{q}}$ \\
\hline Iron & 0.1103 & 0.0258 & 0.0526 & 0.0136 \\
\hline Zinc & 0.2421 & 0.0309 & 0.3206 & 0.0341 \\
\hline Copper & 0.0211 & 0.0113 & 0.0108 & 0.0053 \\
\hline Aluminium & 0.2417 & 0.0316 & 0.1531 & 0.0228 \\
\hline Manganese & 0.0290 & 0.0145 & 0.1796 & 0.0359 \\
\hline Nickel & 0.1448 & 0.0297 & 0.0068 & 0.0069 \\
\hline
\end{tabular}

Table 6. Second-order pseudo kinetics parameters for LHC.

\begin{tabular}{||c|c|c|c|c|c|c||}
\hline \multirow{2}{*}{ Heavy Metal } & \multicolumn{3}{|c|}{$\mathbf{1 0 0} \mathbf{g}$} & \multicolumn{3}{|c|}{$\mathbf{2 0 0} \mathbf{g}$} \\
\cline { 2 - 7 } & $\boldsymbol{R}^{2}$ & $\boldsymbol{Q}_{e}$ & $\boldsymbol{Q}_{t}$ & $\boldsymbol{R}^{2}$ & $\boldsymbol{Q}_{e}$ & $\boldsymbol{Q}_{t}$ \\
\hline Iron & 0.9923 & 0.0094 & 0.0092 & 0.8972 & 0.0094 & 0.0076 \\
\hline Zinc & 0.1444 & 0.0136 & 0.0056 & 0.8802 & 0.0110 & 0.0059 \\
\hline Copper & 0.9912 & 0.0075 & 0.0073 & 0.8801 & 0.0083 & 0.0045 \\
\hline Aluminium & 0.2297 & 0.0071 & 0.0030 & 0.9855 & 0.0098 & 0.0095 \\
\hline Manganese & 0.9337 & 0.0023 & 0.0019 & 0.9737 & 0.0011 & 0.0011 \\
\hline Nickel & 0.9774 & 0.0015 & 0.0015 & 0.9691 & 0.0014 & 0.0013 \\
\hline
\end{tabular}




\section{Conclusions and recommendations}

The study shows that locust beans husk char has strong affinity for aluminium, manganese and nickel removal from contaminated surface water at a $100 \mathrm{~g}$ adsorbent dosage. Removal efficiency for manganese and nickel was greater than $85 \%$ after $150 \mathrm{~min}$ retention time. The removal efficiency pattern for all the heavy metals indicates the relationship among detention time, biosorbent dosage and sorbate under consideration. Further studies could be conducted to inspect this relationship. Effect of activated locust beans husk on heavy metal removal could also be investigated. Calcium composition in a biosorbent suggests that the ion exchange mechanism took place during sorption, and chemisorption was equally noted at some point in the process. The Freundlich isotherm provides a close fit for all the heavy metals considered in the removal process study $\left(R^{2}>0.91\right)$. Second-order kinetics proves to be a better adsorption process description tool particularly for manganese and nickel under both adsorbent dosage conditions $\left(R^{2}>0.93\right)$. The feasibility and suitability of locust beans husk char, a low cost and environment-friendly post-harvest waste, as the biosorbent in aluminium, manganese and nickel diminution from polluted surface water were established in this study.

\section{References}

Ajayi-Banji, A. A. (2012). Physiochemical and microbial treatment of polluted surface waters using chars and activated chars from cattle bone and horn. M.Sc. Thesis submitted to Agricultural and Environmental Engineering Department, University of Ibadan, Nigeria.

Bailey, S. E., Olin, T. J., Bricka, R. M. \& Adrian, D. D. (1999). A review of potential low cost sorbents for heavy metals. Water Research, 33: $2469-2479$. http://dx.doi.org/10.1016/S0043-1354(98)00475-8.

Bogner, J., Ahmed, M. A., Diaz, C., Faaij, A., Gao, Q., Hashimoto, S., Mareckova, K., Pipatti, R. \& Zhang, T. (2007). Waste management, in climate change mitigation. Contribution of working group III to the fourth assessment report of the Intergovernmental Panel on Climate Change, Cambridge University Press, Cambridge, United Kingdom and New York, USA.

Chojnacka, K. \& Michalak, I. (2009). Using wood and bone ash to remove metal ions from solutions. Global NEST Journal, 11(2): $205-217$.

Dizadji, N., Anaraki, N. A. \& Nouri, N. (2011). Adsorption of chromium and copper in aqueous solutions using tea residue. International Journal of Environmental Science and Technology, 8(3), 631-638. http://dx.doi.org/10.1007/BF03326248.

Emmanuel, K. A. \& Veerabhadra Rao, A. (2009). Comparative study of adsorption of $\mathrm{Mn}$ (II) from aqueous solutions on various activated carbon. EJournal of Chemistry, 6 (3), $693-704$. http://dx.doi.org/10.1155/2009/587159.
Hanc, A., Szakova, J. \& P. Svela (2012) Effect of composting on the mobility of arsenic, chromium and nickel contained in kitchen and garden waste. Bioresource Technology, 126, 444-452. http://dx.doi.org/10.1016/j.biortech.2011.11.053.

Ijaola, O. O., Ogedengbe, K. \& Sangodoyin, A. Y. (2013). Kinetic study of water contaminants adsorption bamboo granular activated and non - activated carbon. International Journal of Engineering and Technology Innovation, 3(4): 289-298.

Kumar, D., Sambi, S. S., Sharma, S. K. \& Kumar, V. (2007). Removal of nickel ions from aqueous solutions on packed bed of zeolite NaX. Chemical Engineering Transactions, 11:191-197.

Lurtwitayapont, S. \& Srisatit, T. (2010). Comparison of $\mathrm{Pb}$ removal by various types of swine bone adsorbents. EnvironmentAsia, 3(1): $32-38$.

Moreno, J. C., Gomez, R. \& Giraldo, L. (2010). Removal of $\mathrm{Mn}, \mathrm{Fe}, \mathrm{Ni}$ and $\mathrm{Cu}$ ions from wastewater using cow bone charcoal. Open Access Materials, 3: 452 - 466. http://dx.doi.org/10.3390/ma3010452.

Ndububa, E. E. \& Uloko, J. O. (2015). Locust beans pod ash as a pozzolanic material in concrete. Proceedings of the International Academic Conference for Sub-Sahara African Transformation \& Development, 3(4): 70 - 76.

Omotosho, O. A. \& Sangodoyin, A. Y. (2013). Production and utilization of cassava peel activated carbon in treatment of effluent from cassava processing industry. Water practice \& Technology, 8(2): 215 - 224.

Sangodoyin, A. Y. \& Ajayi-Banji, A. A. (2013). Utilization of abattoir solid wastes as biosorbents for surface water treatment. International Journal of Engineering Inventions, 2(11): $42-47$.

Sekhula, M. M., Okonkwo, J. O., Zvinowande, C. M., Agyer, N. N. \& Chaudhary, A. J. (2012). Dixed bed column adsoption of $\mathrm{Cu}$ (II) onto maize tassel-PVA beads. Chemical Engineering and Process Technology, 3(2): $1-5$. http://dx.doi.org/10.4172/2157-7048.1000131.

Sivakumar, P. \& Palanisamy, P. N. (2009). Packed bed column studies for the removal of acid blue 92 and basic red 29 using non-convectional adsorbent. Indian Journal of Chemical Technology, 16: $301-307$.

Wilson, J. A., Pulford, I. D., \& Thomas, S. (2003). Sorption of $\mathrm{Cu}$ and $\mathrm{Zn}$ by bone charcoal. Environment Geochemistry and Health, 25: $51-56$. http://dx.doi.org/10.1023/A:1021288529358. 


\title{
Sunkiųuụ metalų atskyrimo panaudojant baltosios Amerikos akacijos pupụ lukštų nuodėgulius efektyvumas
}

\author{
Ademola A. Ajayi-Banji ${ }^{1}$, Temitayo A. Ewemoje ${ }^{2}$ ir Olaniyi A. Ajimo ${ }^{3}$ \\ ${ }^{I}$ Žemès ūkio ir biosistemy inžinerijos departamentas, Inžinerijos ir technologijos fakultetas, Ilorin universitetas, \\ Ilorin, Kwara valstija, Nigerija \\ ${ }^{2}$ Žemès ūkio ir biosistemų inžinerijos departamentas, Technologijos fakultetas, Ibadan universitetas, Ibadan, \\ Oyo State valstija, Nigerija \\ ${ }^{3}$ Civilinès inžinerijos departamentas, Inžinerijos mokykla, Yaba technologijos koledžas, Jibowu, Lagos valstija, \\ Nigerija
}

(gauta 2015 m. rugsèjo mèn.; priimta spaudai 2015 m. mèn.)

\begin{abstract}
Dauguma kietųų atliekų tvarkymo sistemų mažai atsižvelgia i mažos koncentracijos bioskaidžias žemės ūkio atliekų tvarkymą, nors šios atliekų kategorijos aplinkosauginis poveikis per tam tikrą laiką yra žymus. Stulpelinis tyrimu siekiama spręsti problemą, pasiūlant potencialų po derliaus nuėmimo likusias atliekas naudoti sunkiesiems metalams atskirti. 100 ir $200 \mathrm{~g}$ baltosios Amerikos akacijos pupų lukštų nuodėguliai buvo panaudoti ištirti kai kurių metalų šalinimo efektyvumą, izoterminius ir kinetinius modelius, kai kontaktinis laikas buvo 30, 60, 90, 120 ir 150 min. Biosorbento elementinè sudètis buvo ištirta naudojant SEM-EDX ịrenginiu. Gauti rezultatai rodo, kad aliuminio ir nikelio šalinimo efektyvumas siekè daugiau nei $85 \%$, kai išlaikymo laikas buvo $150 \mathrm{~min}$. Froindlicho izoterma išsamiai apibūdino daugelio sorbatų sorbciją $(\mathrm{R} 2>=0.91)$. Sorbcijos dydis vienodai tiko ị antrini pseudo kinetinị modelị $(\mathrm{R} 2>=0.88)$. Jon kaita vyko sorbcijos metu. Baltosios Amerikos akacijos pupų lukštai turi perspektyvų adsorbcijos potencialą šalinant sunkiųų metalų jonus iš nešvaraus paviršinio vandens.

Raktiniai žodžiai: po derliaus nuémimo likusios atliekos, šalinimo efektyvumas, izoterma, kinetine sorbcija, baltosios Amerikos akacijos pupu lukštu nuodèguliai.
\end{abstract}

